\title{
Encapsulation of Allyl Sulfide with Middle-Chain Triglyceride Oil and Cyclodextrin by Spray Drying
}

\author{
Thi Van Anh NGUYEN ${ }^{1,2,3}$, Hidefumi YOSHII ${ }^{1,2, \dagger}$ \\ ${ }^{1}$ Department of Applied Biological Science, Kagawa University, 2393, Ikenobe, \\ Miki-cho, Kita-gun, Kagawa 761-0795, Japan \\ ${ }^{2}$ Applied Bioresource Department, The United Graduate School of Agricultural Sciences, \\ Ehime University, 3-5-7 Tarumi, Matsuyama, Ehime 790-8566, Japan \\ ${ }^{3}$ Faculty of Agricultural Engineering and Food Technology, Hue University of Agriculture and Forestry, \\ 102 Phung Hung, Hue, Thua Thien Hue, Vietnam
}

\begin{abstract}
Volatile sulfur compounds are very important in the contribution or sensory analysis of flavors in many foods. The molecular inclusion of flavor in cyclodextrin (CD) is one technique to protect against the degradation of labile flavor. Encapsulation of diluted allyl sulfide in middle-chain triglyceride (MCT) oil with cyclodextrin as a wall material was investigated using a spray dryer. A carrier solution was prepared by dissolving $\alpha-, \beta-$, or $\gamma-\mathrm{CD}$ in distilled water. Allyl sulfide $(10,000 \mathrm{ppm})$ in an MCT and CD solution was homogenized and incubated at $30^{\circ} \mathrm{C}$ for $8 \mathrm{~h}$. This incubated solution was spray dried in a mini spray dryer. Spray-dried powder containing allyl sulfide was obtained with an allyl sulfide content of $0.78 \mathrm{mg} / \mathrm{g} \mathrm{CD}$ for $\alpha-\mathrm{CD}, 0.17$ for $\beta-\mathrm{CD}$, and 0.63 for $\gamma-\mathrm{CD}$ at an inlet air temperature of $200^{\circ} \mathrm{C}$. The content of allyl sulfide in the powder was affected by the concentration of allyl sulfide in the MCT oil and the content of MCT oil in the feed solution. The inlet air temperature did not affect the content of allyl sulfide in the CD powder. The incubation of allyl sulfide in the MCT oil and $\mathrm{CD}$ solution formed an inclusion complex of allyl sulfide in the $\mathrm{CD}$ powder. It was also shown that the lettuces under supercooled conditions keep the initial state of the water and sugar contents by reducing the respiration rate, and that the risk of foodborne illness is improved by keeping the number of the bacteria in low level even after the supercooled storages for three weeks.
\end{abstract}

Keywords: Encapsulation, cyclodextrin, spray drying, allyl sulfide, inclusion complex.

\section{Introduction}

Volatile sulfur compounds are very important in the contribution or sensory analysis of flavor in many foods [1]. Allyl sulfide (or diallyl sulfide) is one garlic oil component that can be used as a food flavor. Garlic oil is recognized as a bio-preservation agent for fresh-cut tomato because of its antimicrobial activity [2], or other pharmacological properties such as antidiabetic, antimutagenic, and anticarcinogenic effects [3]. Allyl sulfide is formed by the decomposition of allicin when garlic tissue breaks down [4]. Pre-cooking treatments and cooking method experiments showed diallyl sulfide was only detected in chopped garlic cooked by simmering and stir-frying but was not found in sliced garlic or whole cloves in any

(Received 4 Nov. 2016: accepted 14 Jan. 2017)

† Fax: +81 87891 3101, E-mail: foodeng.yoshii@ag.kagawa-u.ac.jp

* Part of this study was presented at the 20th International Drying Symposium (Gifu, August 7-10, 2016) cooking method [5]. Sulfur flavor compounds have high heat labile stability and strong pungent odors. Santhosha et al. [4] suggested garlic oil was better to use when diluted with vegetable oil or in an encapsulated form. Ayala-Zavala and González-Aguilar [6] investigated the encapsulation of garlic oil in $\beta$-cyclodextrin $(\beta-C D)$ and the release behaviors of allyl sulfide from the inclusion complex powder under humid conditions. CDs are doughnut-shaped cyclic oligosaccharides with an interior cavity, and they form specific inclusion complexes with many organic compounds. CDs are considered suitable for encapsulating because of their special structure. The inclusion complex of garlic oil in $\beta-\mathrm{CD}$ has been formed using the precipitation method and dried in a conventional oven at $50^{\circ} \mathrm{C}$ for $24 \mathrm{~h}$ [7]. CDs have been used as flavor carriers, protectants of food ingredients, undesired taste masking, and food packaging materials $[8,9]$.

Encapsulation of flavor is one technique to convert liq- 
uid flavors into solid flavors, which are easy to handle [10]. Encapsulation can be done by physical methods such as spray drying and freeze drying, by kneading, or by chemical methods such as coacervation and molecular encapsulation [11-13]. Although many encapsulation techniques have been developed, spray drying is the most appropriate method to form flavor-encapsulated powder because of its low cost, simple and continuous operating system, and powdering ability [14,15]. Reineccius et al. [16] investigated the encapsulation of flavors using CDs. Bhandari et al. [17] investigated the microencapsulation of lemon oil by kneading with $\beta$ cyclodextrin and vacuum drying or spray drying. By using the co-precipitation method, Wang et al. [18] reported an inclusion complex of garlic oil and $\beta-\mathrm{CD}$ formed in a molar ratio of $1: 1$. The formation of a $1: 1$ inclusion complex between a volatile flavor compound and $\alpha-, \beta-$, and $\gamma-\mathrm{CD}$ has been shown [19]. Shiga et al. [20] investigated flavor encapsulation and the release characteristics of spray-dried powder using the blended encapsulant of cyclodextrin and gum arabic. Kawakami et al. [21] investigated the formation of rice-flavor powder with $\alpha-\mathrm{CD}$ by spray drying. The release characteristics of flavor from spray-dried powder in boiling water and rice cooking were reported by Shiga et al. [22].

Commercial garlic essential oil was used in diluted form and vegetable oils were usually chosen as the diluting solvents [23]. MCT was used as a water insoluble solvent for oral formulations [24]. When triglyceride is dispersed in a CD solution, $C D$ acts as an emulsifier or surfactant at the oil/water interface [25-28]. Szejtli [29] indicated $\beta-\mathrm{CD}$ formed an inclusion complex with cholesterol from low-cholesterol butter and suggested cholesterol had a higher affinity to $\beta-\mathrm{CD}$ than triglycerides.
Mathapa and Paunov [30] reported that microcrystals of cyclodextrin-oil inclusion complexes could stabilize $\mathrm{O} /$ W emulsions. Reineccius et al. [31] investigated the competition between flavor solvents and flavors to form molecular inclusion complexes with $\alpha-\beta-$, and $\gamma-\mathrm{CD}$ and showed the smallest and most polar solvent molecule had the least effect on $\mathrm{CD} /$ flavor complex formation. Several studies investigated the emulsifying ability of oil-CD complexes. The inclusion complex solution of CDs and flavor after incubation has to form dry powder. Spray drying might be the better drying method for this inclusion complex solution for heat labile flavor such as for allyl sulfide because the drying time in spray drying is very short. However, there are no reports on the encapsulation of allyl sulfide diluted in MCT oil using CDs by kneading and spray drying.

In this study, the encapsulation of allyl sulfide diluted in MCT oil and CDs was investigated by spray drying. The efficiency of forming an inclusion complex of allyl sulfide was studied by investigating the effect of CDs, allyl sulfide, and MCT oil concentrations on the retention of allyl sulfide in spray-dried powder. The characteristics of the allyl sulfide-MCT oil-CD inclusion complex powders were investigated.

\section{Materials and methods}

\subsection{Materials}

Cyclodextrin ( $\alpha, \beta$, and $\gamma$ ) was purchased from Wako Pure Chemical Co., Ltd. (Tokyo, Japan). MCT oil (Riken Vitamin Co., Ltd.) and allyl sulfide (98\% purity; Tokyo Chemical Industry Co., Ltd.) were used. Anisole (methoxybenzene, 99\%) was bought from Wako Pure Chemical Industries, Ltd. Other analytical grade chemi-

Table 1 Physical characteristics of the CD encapsulated spray-dried powders.

\begin{tabular}{|c|c|c|c|c|c|}
\hline $\begin{array}{l}\text { Type } \\
\text { of CD }\end{array}$ & $\begin{array}{l}\text { Inlet temperature } \\
\qquad\left({ }^{\circ} \mathrm{C}\right)\end{array}$ & $\begin{array}{l}\text { Moisture } \\
\text { content } \\
(\%)\end{array}$ & $\begin{array}{l}\text { Flavor content } \\
\text { (mg allyl sulfide/g } \\
\text { CD) }\end{array}$ & $\begin{array}{l}\text { Powder diameter } \\
\qquad(\mu \mathrm{m})\end{array}$ & $\begin{array}{c}\text { Initial crystal } \\
\text { diameter }(\mu \mathrm{m})\end{array}$ \\
\hline \multirow{3}{*}{$\alpha-\mathrm{CD}$} & 140 & 5.59 & $0.73 \pm 0.022$ & $9.61 \pm 0.81$ & \multirow{3}{*}{$8.09 \pm 0.21$} \\
\hline & 160 & 5.79 & $0.72 \pm 0.003$ & $10.86 \pm 0.34$ & \\
\hline & 200 & 5.49 & $0.78 \pm 0.006$ & $6.96 \pm 0.8$ & \\
\hline \multirow{3}{*}{$\beta-\mathrm{CD}$} & 140 & 10.69 & $0.14 \pm 0.01$ & $14.95 \pm 0.94$ & \multirow{3}{*}{$9.66 \pm 0.27$} \\
\hline & 160 & 7.84 & $0.16 \pm 0.006$ & $11.49 \pm 0.61$ & \\
\hline & 200 & 4.54 & $0.17 \pm 0.008$ & $11.49 \pm 0.61$ & \\
\hline \multirow{3}{*}{$\gamma-\mathrm{CD}$} & 140 & 8.81 & $0.61 \pm 0.02$ & $11.95 \pm 0.81$ & \multirow{3}{*}{$3.15 \pm 0.11$} \\
\hline & 160 & 6.78 & $0.60 \pm 0.006$ & $11.61 \pm 0.03$ & \\
\hline & 200 & 6.03 & $0.63 \pm 0.02$ & $11.21 \pm 0.51$ & \\
\hline
\end{tabular}


cals were from Wako Pure Chemical Co., Ltd. (Tokyo, Japan).

\subsection{Preparation of slurry}

The carrier solution was prepared by dissolving $\mathrm{CD}$ $\left(\alpha, \beta\right.$, and $\gamma$ ) in distilled water at $50^{\circ} \mathrm{C}$. The flavor was allyl sulfide dissolved in MCT oil. The concentration of allyl sulfide in the MCT oil was 1,000, 5,000, 10,000, and $20,000 \mathrm{ppm}$. The solid content of the solution was $30 \mathrm{wt} \%$ and the MCT oil content of the total solids was 5,10 , and 15 wt\%. The solutions were homogenized using a Polytron homogenizer (PT10-35; Kinematica Ag Littau, Switzerland) at $10,000 \mathrm{rpm}$ for $3 \mathrm{~min}$. This solution was then incubated at $30^{\circ} \mathrm{C}$ for $8 \mathrm{~h}$ at a shaking speed of 150 rpm using a shaker (NTS-1300; Eyela).

\subsection{Microencapsulation by spray drying}

Flavor slurries were spray dried in a B-290 Mini Spray Dryer (Buchi). The spray drying conditions were as follows: emulsion flow rate, $10 \mathrm{~mL} / \mathrm{min}$; airflow rate, $35 \mathrm{~m}^{3} /$ $\mathrm{h}$; inlet air temperature, $140,160,180$, and $200^{\circ} \mathrm{C}$; and outlet air temperature, $61-97^{\circ} \mathrm{C}$. The temperature of the feed slurry was kept at $30^{\circ} \mathrm{C}$. The spray-dried encapsulation powders were stored at $-30^{\circ} \mathrm{C}$ in nitrogen-filled bags until they were used for analysis.

\subsection{Analysis of crystal size and powder diameter}

The crystal size of the slurries and powder diameter were measured by using a nano particle size analyzer (SALD-7100; Shimadzu, Kyoto, Japan). To analyze the crystal size of the slurry, $50 \mu \mathrm{L}$ emulsion was added to a glass tube containing $3 \mathrm{~mL}$ distilled water. In measuring the powder diameter, 2-methyl 1-propanol was used instead of distilled water.

\subsection{Retention of allyl sulfide}

Distilled water $(2 \mathrm{~g})$ was added to $0.1 \mathrm{~g}$ spray-dried powder in a glass bottle. Then, $3 \mathrm{~mL}$ hexane, which contained anisole as the internal standard, was added to the glass bottle, and a cap was tightly fitted to the bottle. To extract the encapsulated allyl sulfide with hexane solution, the mixture was heated at $90^{\circ} \mathrm{C}$ for $30 \mathrm{~min}$ (every $10 \mathrm{~min}$, the glass bottle was shaken for 3 min using a vortex). The extracted mixture was centrifuged at 3,000 rpm for $10 \mathrm{~min}$ and the allyl sulfide content was measured using a gas chromatograph (GC-2010; Shimadzu Corporation, Kyoto, Japan). The GC conditions were as follows: column, fused silica capillary $30 \mathrm{~m} \times 0.25 \mathrm{~mm} \times 0.5 \mu \mathrm{m}$ (Ulbon HR-1; Shinwa
Chemical Industries Ltd., Kyoto, Japan); detector, flame ionization, $200^{\circ} \mathrm{C}$; carrier gas, nitrogen, $70 \mathrm{kPa}$; column temperature, constant at $80^{\circ} \mathrm{C}$.

The allyl sulfide content in the spray-dried powders was defined as follows:

$$
\text { Flavor content }=\frac{W_{a s}}{W_{w m}}
$$

where $W_{a s}$ is the weight of the allyl sulfide $(\mathrm{mg})$ and $W_{w m}$ is the weight of dry wall material (CD) $(\mathrm{g})$. All the samples were analysed in duplicate and the data were presented as an average.

\subsection{Scanning electron microscopy}

The morphology of the encapsulated powder was evaluated using a scanning electron microscope (SEM) (JSM 6060; Jeol)

\subsection{Powder x-ray diffractometry}

The $\mathrm{x}$-ray powder diffraction patterns were obtained with a Rint 2500 X-ray Diffractometer (Rigaku) using $\mathrm{Ni}$-filtered, $\mathrm{Cu} \mathrm{K} \alpha$ radiation, at $40 \mathrm{kV}$ and $30 \mathrm{~mA}$. The initial CD powders and the encapsulated powders were measured in the $2 \theta$ angle range between $0^{\circ}$ and $60^{\circ}$ with a scan rate of $1^{\circ} / \mathrm{min}$ and step size $0.1^{\circ}$

\section{Results and discussion}

\subsection{Formation of the allyl sulfide-MCT oil- CD emulsion}

Figure 1 shows the microscopic images of crystals encapsulated in $\alpha-, \beta-$, and $\gamma-\mathrm{CD}$ in $\mathrm{CD}$ slurry before and after incubation (these photos are images of the samples at 30 wt\% solid content and 10\% MCT oil with 10,000 ppm allyl sulfide). These crystal images were taken before and after incubation of samples of the mixture of $\mathrm{CD}$ and MCT oil containing allyl sulfide that were centrifuged. As shown in Fig. 1, the crystal size of $\beta-\mathrm{CD}$ decreased during incubation. Because $\alpha-\mathrm{CD}$ formed needle crystals, which might be the inclusion complex crystal of MCT oil and/or allyl sulfide, the crystal size distribution broadened compared with the initial solution (Fig. 2). MCT oil and allyl sulfide concentration did not affect the crystal shape and crystal size distribution. Mathapa and Paunov [30] reported that microrods of $\alpha$-CD-tetradecane were longer than that of $\beta-\mathrm{CD}$-tetradecane. The homogenized solution contained emulsified oil droplets with the inclusion complex of MCT oil in the CDs. These CD crystals were the inclusion complex of allyl sulfide and MCT oil. Shimada et al. [32] reported the formation of inclusion complexes of cyclodex- 


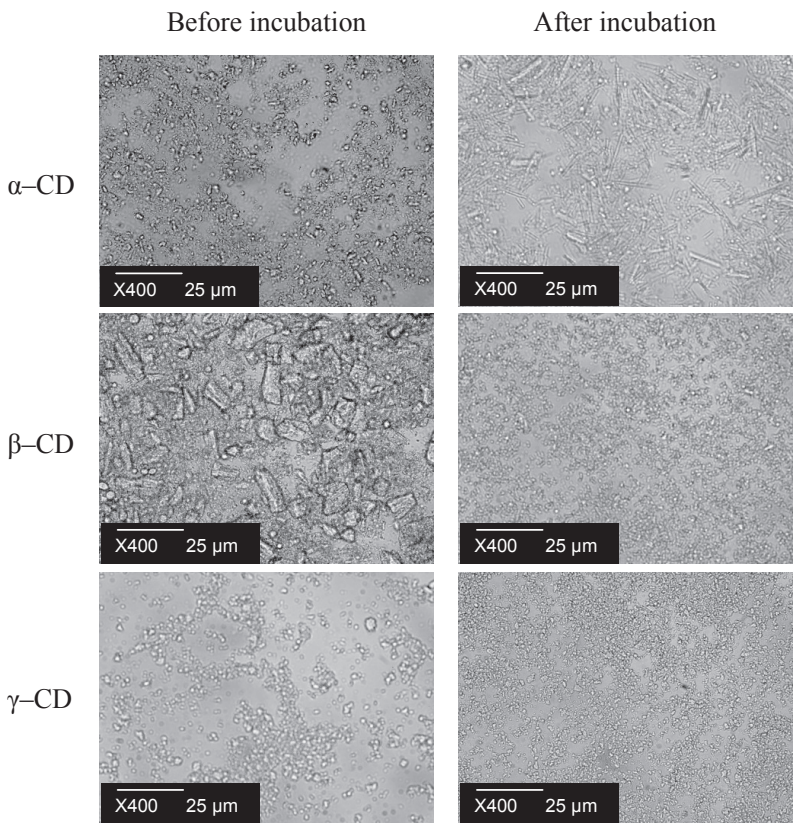

Fig. 1 Microscopic images of the crystal layer of the allyl sulfide-CD slurry obtained at solid content of $30 \%$ and MCT oil content was $10 \%$ of total solid content. (The crystal layer was separated from the bottom layer of the centrifuged incubated inclusion complex solution.)

trins with triglyceride at the vegetable oil/water interface and suggested $\mathrm{CD}$ formed the inclusion complex with the triglyceride. Mathapa and Paunov [30] showed photographs of the inclusion complex with $\mathrm{CD}$ and tetradecane. $\alpha-\mathrm{CD}$-tetradecane crystals were needle crystals and $\beta-$ CD-hexadecane crystals had a spherical structure.

\subsection{Allyl sulfide encapsulation efficiency}

Figure 3 shows the encapsulation efficiency of three types of $\mathrm{CD}: \alpha-, \beta-$, and $\gamma-\mathrm{CD}$ at various allyl sulfide concentrations. As can be seen from Fig. 3, the allyl sulfide content in the inclusion complex powders increased with the increase in allyl sulfide concentration in the MCT oil. The allyl sulfide concentration in $\alpha-\mathrm{CD}$ and $\gamma-$ $\mathrm{CD}$ was about $0.7 \mathrm{mg} / \mathrm{g} \mathrm{CD}$ powder and $0.6 \mathrm{mg} / \mathrm{g}$ powder, respectively, at 10,000 ppm allyl sulfide in the MCT oil. On the other hand, the allyl sulfide concentration in $\beta-\mathrm{CD}$ was $0.2 \mathrm{mg} / \mathrm{g} \mathrm{CD}$. The content of allyl sulfide might be affected by the solubility of CDs when considering film formation during spray drying.

Figure 4 shows the effect of MCT oil concentration on allyl sulfide concentration in the $\mathrm{CD}$ powders. The increment lines for $\alpha-\mathrm{CD}$ and $\beta-\mathrm{CD}$ were convex upward and straight for $\gamma-\mathrm{CD}$. The increments of allyl sulfide content in $\mathrm{CD}$ indicated the complexation formation of allyl sulfide in $\mathrm{CD}$ might be stronger than $\mathrm{MCT}$ in $\mathrm{CD}$. These results indicated the MCT oil content affected the binding behavior of allyl sulfide in $\mathrm{CD}$.

In inclusion complex formation with cyclodextrin, Mathapa and Paunov [30] investigated the preparation of an oil/water emulsion stabilized by a microcrystalline CD-oil inclusion complex. They considered the adsorbed inclusion-complex crystal on oil droplets to be a Pickering emulsion. Inoue et al. [26] also investigated an $n$-alkane/water emulsion stabilized by cyclodextrin. In
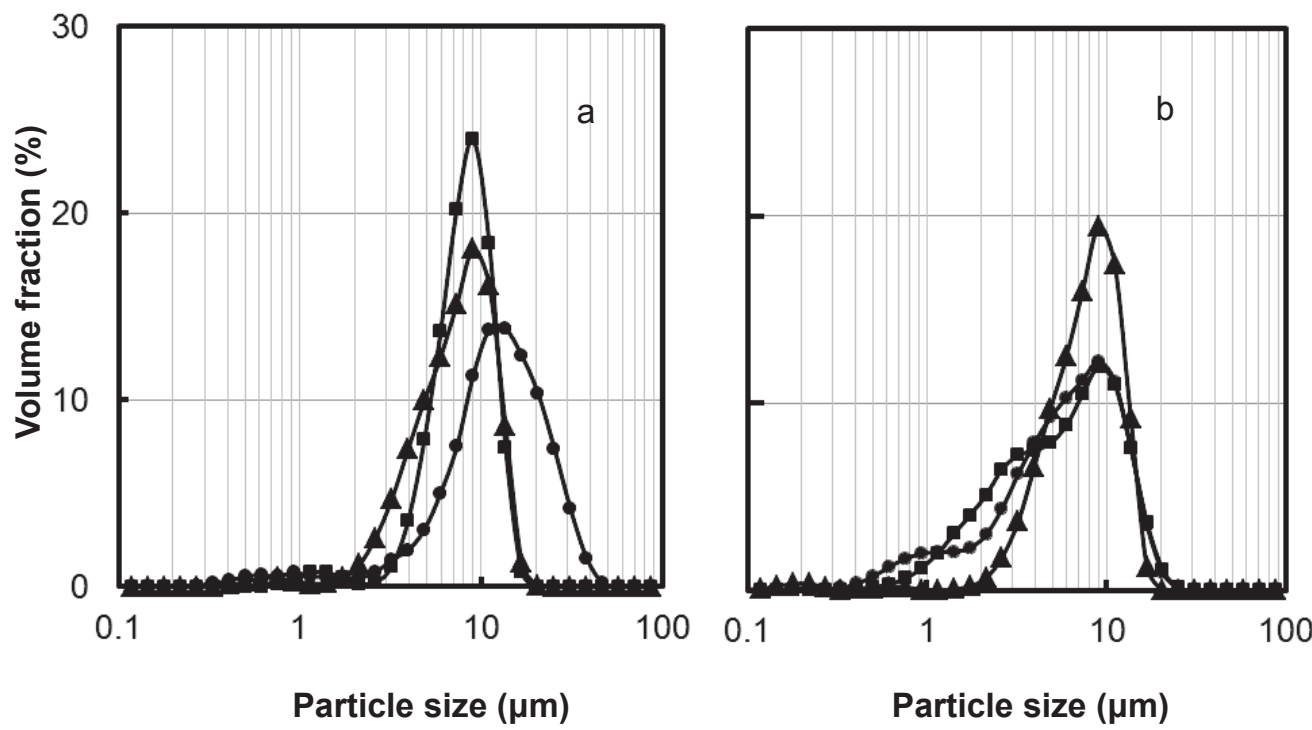

Fig. 2 Particle size of the $\alpha-C D, \beta-C D$, and $\gamma-C D$ inclusion complex (MCT oil/total solids, $10 \%$; allyl sulfide concentration, $10,000 \mathrm{ppm}$ ) before incubation (a) and after incubation (b). ( $\square \alpha-\mathrm{CD}, \bigcirc \beta-\mathrm{CD}$, - $\gamma-\mathrm{CD})$ 


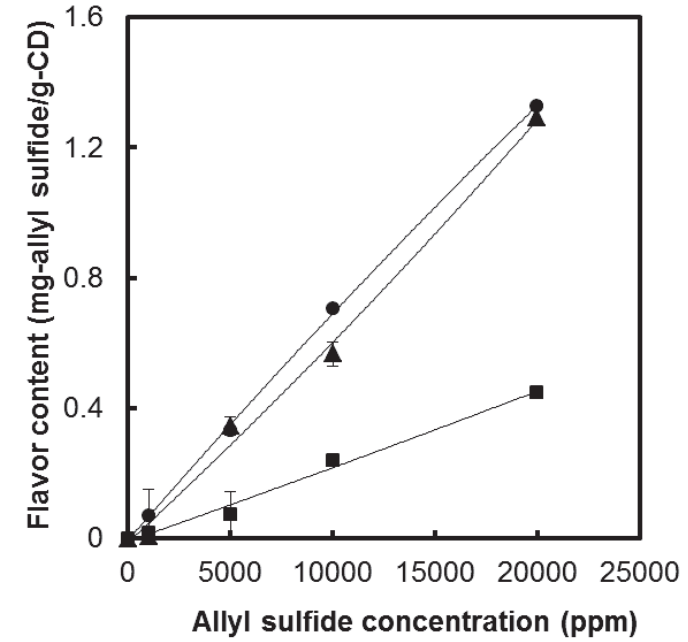

Fig.3 Effect of allyl sulfide concentration on flavor content (MCT oil/total solids, $10 \%)$. ( $\alpha-\mathrm{CD}, \boldsymbol{\beta}-\mathrm{CD}, \boldsymbol{\gamma} \gamma-\mathrm{CD})$

our system, the incubation solution of CD, MCT oil, and water was a slurry containing CD crystals. Therefore, some parts of the inclusion complex crystal might adsorb the oil as a Pickering emulsion. Those phenomena might affect flavor retention during spray drying. This effect of a Pickering emulsion and characterization has been investigated.



Fig.4 Effect of MCT oil concentration on flavor content (allyl sulfide in MCT oil, 10,000 ppm). ( $\alpha-\mathrm{CD}, \boldsymbol{\square} \beta-\mathrm{CD}, \boldsymbol{\Delta} \gamma-\mathrm{CD})$

\subsection{Morphology of encapsulated powders}

SEM images of the encapsulated powders are shown in Fig. 5. The morphology of the encapsulated powders differed from the initial crystals as shown in Fig. 1. Rusa et al. [33] reported that $\alpha-$ and $\gamma-\mathrm{CD}$ powder could be recrystallized using aqueous solutions. Under appropriate solvent conditions, columnar (channel structure) $\alpha-$

b

C

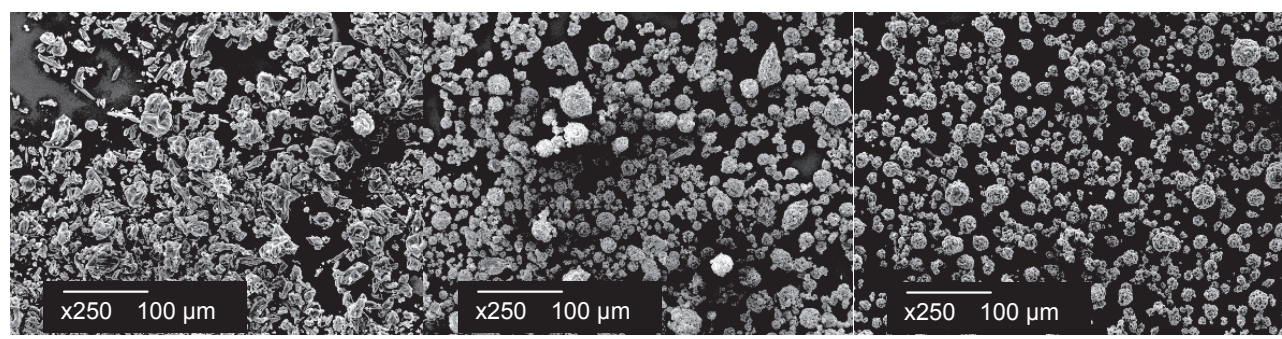

a'

b'

$\mathrm{C}^{\prime}$

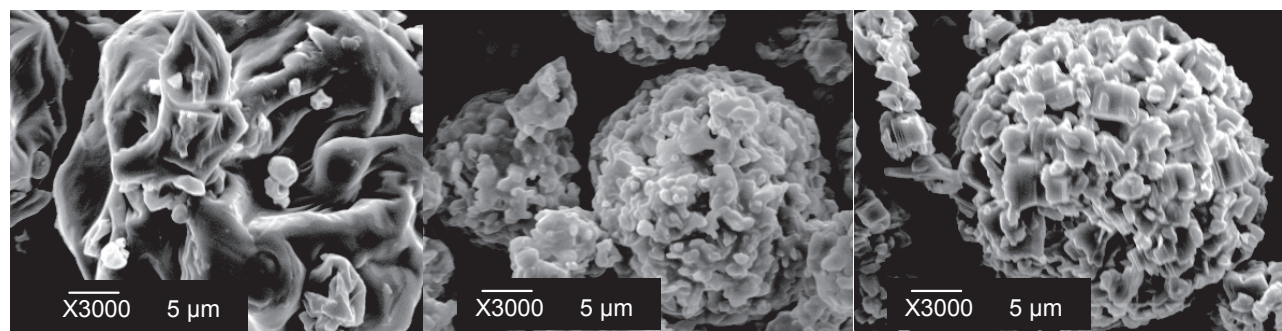

A

B

C

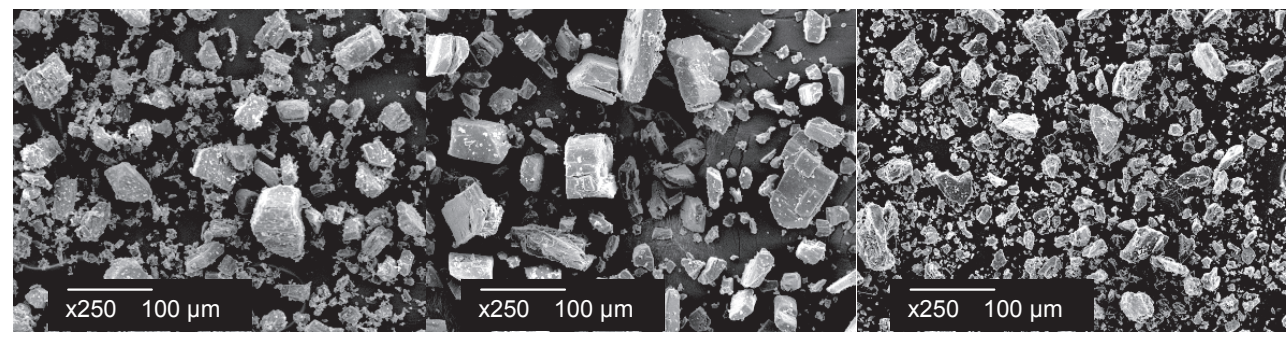

Fig.5 SEM images of encapsulated spray-dried powder with $\alpha-C D$ (a and a'), $\beta-C D$ (b and b'), and $\gamma-$ $\mathrm{CD}$ (c and c') at magnification 250 (a, b, and c) and 3000 (a', b', and c'); A, B, and C are $\alpha-C D, \beta-C D$, and $\gamma-\mathrm{CD}$ crystals. 
and $\gamma-\mathrm{CD}$ could be formed. A channel structure was stable for $\alpha-\mathrm{CD}$ after vacuum drying, whereas $\gamma-\mathrm{CD}$ in a channel structure underwent phase transition and then transformed to $\gamma-\mathrm{CD}$ in an amorphous structure. Ho and Bhandari [34] suggested the encapsulation efficiency of amorphous $\alpha-\mathrm{CD}$ was higher than that of normal $\alpha-\mathrm{CD}$

$\beta-$ and $\gamma-\mathrm{CD}$ encapsulated powders had globular shapes with a smooth and steady surface. These globular shapes were built from many trapezoidal pieces. Meanwhile, $\alpha-\mathrm{CD}$ encapsulated powders had a globular shape with a wrinkled surface.

Figure 6 shows $\mathrm{x}$-ray diffractograms of the encapsulated powders. The $\mathrm{x}$-ray diffractograms of the spraydried powders had broader peaks than those of the original CD crystals. This finding indicated that the spraydried powder was in an amorphous state and explained why the encapsulation efficiency of the $\beta-\mathrm{CD}$ powder was lower than those of both the $\alpha-$ and $\gamma-\mathrm{CD}$ powders. Rusa et al. [33] reported that the peak at $2 \theta \sim 20^{\circ}$ in the wide angle $\mathrm{x}$-ray diffraction of the $\alpha-\mathrm{CD}$ inclusion compound featured a channel structure for $\alpha-C D$. This conclusion indicated that the encapsulated $\alpha-\mathrm{CD}$ powder contained a channel structure for the $\alpha-C D$ inclusion complex. According to Rusa et al. [33] the structure of $\alpha$ -CD would be stable after the drying process, which was why $\alpha-C D$ had the highest allyl sulfide retention. Moreover, the peak at $2 \theta \sim 7.6^{\circ}$, which has been suggested as an indicator channel structure, was found in the $\mathrm{x}$-ray diffraction of the encapsulated $\gamma-\mathrm{CD}$ powder. Therefore, it could be concluded that the encapsulated $\gamma-C D$ powder had a channel structure for the $\gamma-C D$ inclusion complex inside.

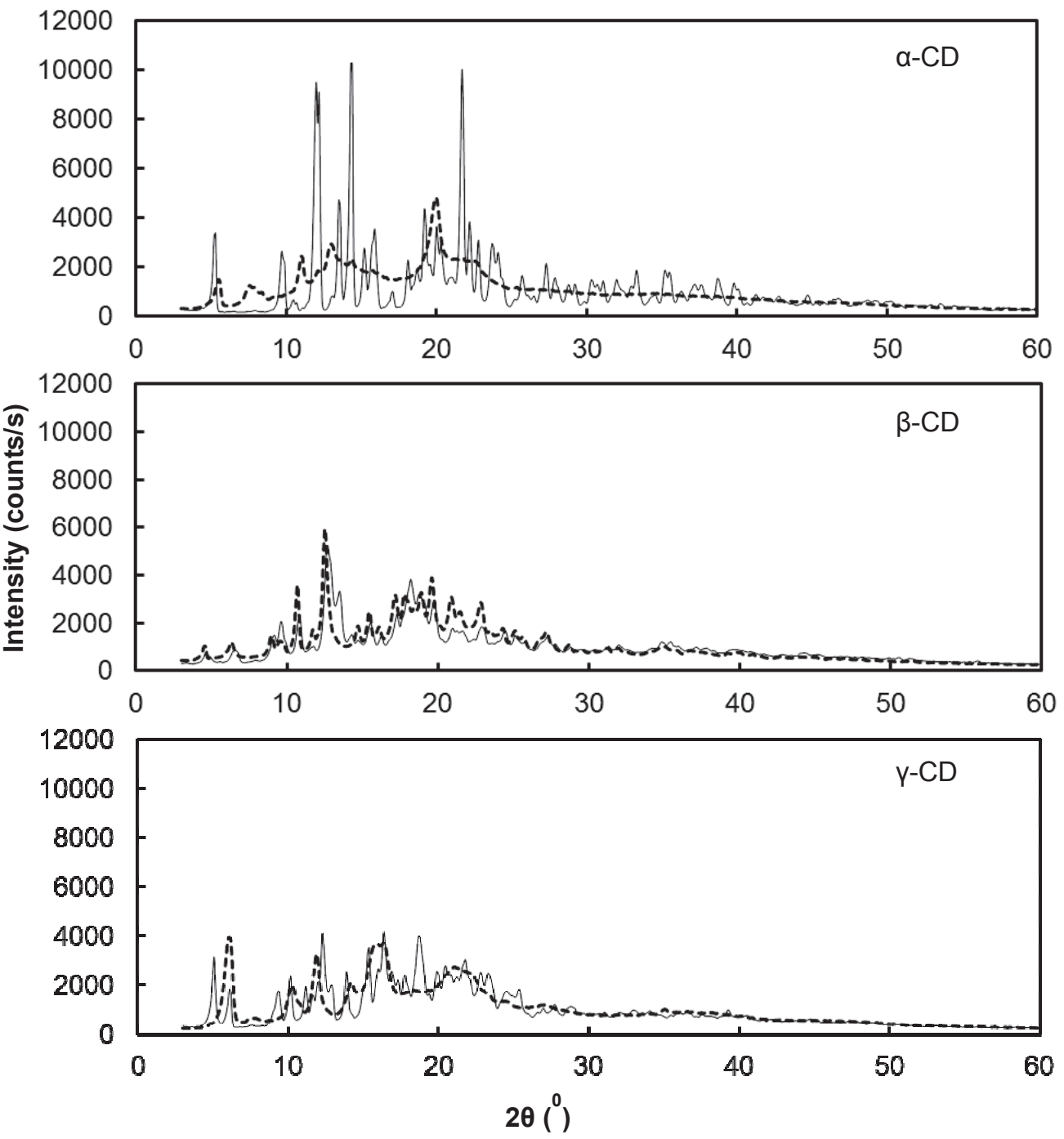

Fig.6 X-ray diffractograms of CD encapsulated spray-dried powders (- -) and CD crystals (-) (MCT oil/ total solids, $10 \%$; allyl sulfide concentration, $10,000 \mathrm{ppm}$ ). 


\subsection{Effect of inlet temperature on}

the physical characteristics of the CD encapsulated spray-dried powders

Inlet air temperature did not affect the allyl sulfide content of the encapsulated spray-dried powder (as shown in Table 1). The size of the encapsulated spray-dried powder changed in the $\alpha$ - and $\beta-\mathrm{CD}$ encapsulated-powders, whereas the encapsulated $\gamma-\mathrm{CD}$ powder size was the same value at different inlet air temperature. These results suggest the size of the spray-dried inclusion complex may depend on the film formation rate of $\mathrm{CD}$ solutions and solubility of CDs. Turchiuli et al. [35] found there was no change in oil droplet size distribution for wall materials of maltodextrin, acacia gum, and a mixture of maltodextrin and acacia gum in various ratios.

\section{Conclusion}

The results of our study illustrated the formation of an allyl sulfide-MCT oil-CD inclusion complex. Flavor content increased with the increase in concentration of allyl sulfide and a mixture of allyl sulfide and MCT oil. Inlet air temperature did not significantly affect flavor content but did affect powder size.

\section{Acknowledgement}

Thi Van Anh Nguyen received the scholarship from the Vietnam Ministry of Education and Training during her study.

\section{References}

1) R. J. McGorrin; "Volatile sulfur compounds in Food," M.C. Qian, X. Fan and K. Mahattanawee ed., ACS Symposium series 1088, 2011, pp. 3-31.

2) J. F. Ayala-Zavala, G. Oms-Oliu, I. Odriozola-Serrano, G. A. González-Aguilar, E. Aslvarez-Parilla, O. Martín-Belloso; Bio-preservation of fresh-cut tomatoes using natural antimicrobials. Eur. Food Res. Technol., 226, 1047-1055 (2008).

3) K. C. Agarwal; Therapeutic actions of garlic constituents. Med. Res. Rev., 16, 111-124 (1996)

4) S. G. Santhosha, P. Jamuna, S. N. Prabhavathi; Bioactive components of garlic and their physiological role in heath maintenance: A review. Food Biosci., 3, 59-74 (2013).

5) D. A. Locatelli, J. C. Altamirano, R. E. González, A. B. Camargo; Home-cooked garlic remains a healthy food. J. Func. Foods, 16, 1-8 (2015)
6) J. F. Ayala-Zavala, G. A. González-Aguilar; Optimizing the use of garlic oil as antimicrobial agent on fresh-cut tomato through a controlled release system. J. Food Sci., 75(7), M398-M405 (2010).

7) J. F. Ayala-Zavala, H. Soto-Valdez, A. GonzálezLeón, E. Aslvarez-Parilla, O. Martín-Belloso, G. A González-Aguilar; Microencapsulation of cinnamon leaf (Cinnamomum zeylanicum) and garlic (Allium sativum) oils in $\beta$-cyclodextrin. J. Incl. Phenom. Macrocycl. Chem., 60, 359-368 (2008).

8) L. Szente, J. Szejtli; Cyclodextrins as food ingredients Trends Food Sci. Tech., 15, 137-142 (2004).

9) A. R. Hedges; Industrial application of cyclodextrins. Chem. Rev., 98, 2035-2044 (1998).

10) A. Soottitantawat, H. Yoshii, T. Furuta, M. Ohkawara, P. Linko; Microencapsulation by spray drying: influence of emulsion size on the retention of volatile compounds. Food Eng. Phys Prop., 68, 2256-2262 (2003)

11) J. D. Dziezack; Microencapsulation and encapsulated ingredients. Food Technol., 42, 136-151 (1988).

12) B. F. Gibbs, S. Kermasha, I. Alli, N. Mulligan; Encapsulation in the food industry: a review. Intl J Food Sci. Nutr., 50, 213-224 (1999)

13) F. Shahidi, X. Q. Han; Encapsulation of food ingredients. Crit. Rev. Food Sci. Nutr., 33, 501-547 (1993).

14) T. Furuta, A. Soottitantawat, T. L. Neoh, H. Yoshii; "Physicochemical aspects of food engineering and processing”, S. Devahastin ed., CRC press, 2010, pp. 3-40.

15) A. Soottitantawat, R. Partanen, T. L. Neoh, H. Yoshii Encapsulation of hydrophilic and hydrophobic flavors by spray drying. Jpn. J. Food Eng., 16, 37-52 (2015).

16) T. A. Reineccius, G. A. Reineccius, T. L. Peppard; The effect of solvent interactions on $\alpha-, \beta-$, and $\gamma$-cyclodextrin/ flavor molecular inclusion complexes. J. Agri. Food Chem. 53, 338-392 (2005).

17) B. R. Bhandari, R. D. Bruce, I. Padukka; Encapsulation of lemon oil by paste method using $\beta$-cyclodextrin Encapsulation efficiency and profile of oil volatiles. J. Agr. Food Chem., 47, 5194-5197 (1999).

18) J. Wang, Y. Cao, B. Sun, C. Wang; Physicochemical and release characterization of garlic oil- $\beta$-cyclodextrin inclusion complexes. Food Chem., 127, 1680-1685 (2011).

19) A. Ciobanu, D. Landy, S. Fourmentin; Complexation efficiency of cyclodextrins for volatile flavor compounds. Food Res. Int., 53, 110-114 (2013).

20) H. Shiga, H. Yoshii, T. Nishiyama, T. Furuta, P. Forssele, K. Poutanen, P. Linko; Flavor encapsulation and release characteristics of spray-dried powder by the blended encapsulant of cyclodextrin and gum arabic. Drying Technol., 19, 
1385-1395 (2001).

21) K. Kawakami, A. Fujita, T. Mikami, H. Yoshii, V. Paramita,

T. L. Neoh, T. Furuta; Formation of rice flavor powder with $\alpha$-cyclodextrin by spray drying. Eur. Food Res. Technol., 229, 239-245 (2009).

22) H. Shiga, H. Yoshii, R. Taguchi, T. Nishiyama, T. Furuta, P. Linko; Release characteristics of flavor from spray-dried powder in boiling water and during rice cooking. Biosci. Biotechnol. Biochem., 67, 426-428 (2003).

23) $\mathrm{H}$. Amagase; Clarifying the real bioactive constituents of garlic. J. Nutr., 136, 716S-725S (2006).

24) R. G. Strickley; Solubilizing excipients in oral and injectable formulations. Pharmaceut. Res., 21, 201-230 (2004).

25) M. Inoue, K. Hashizaki, H. Taguchi, Y. Saito; Emulsion preparation using $\beta$-cyclodextrin and its derivatives acting as an emulsifier. Chem. Pharm. Bull., 56, 1335-1337 (2008).

26) M. Inoue, K. Hashizaki, H. Taguchi, Y. Saito; Preparation and characterization of $n$-alkane/water emulsion stabilized by cyclodextrin. J. Oleo Sci., 58, 85-90 (2009).

27) K. Shimada, K. Ohe, T. Ohguni, K. Kawano, J. Ishii, T. Nakamura; "Emulsifying properties of $\alpha-\beta$ - and $\gamma$-cyclodextrins" (in Japanese). Nippon Shokuhin Kygyo Gakkai, 38, 16-20 (1991).

28) D. Duchêne, A. Bochot, S. C. Yu, C. Pépin, M. Seiller; Cyclodextrins and emulsions. Int. J. Pharm., 26, 85-90
(2003).

29) J. Szejtli; Utilization of cyclodextrins in industrial products and processes. J. Mater. Chem., 7, 575-587 (1997).

30) B. G. Mathapa, V. N. Paunov; Cyclodextrin stablilised emulsions and cyclodextrinosomes. Phys. Chem. Chem. Phys., 15, 17903-17914 (2013).

31) T. A. Reineccius, G. A. Reineccius, T. L. Peppard; The effect of solvent interactions on $\alpha-, \beta-$, and $\gamma$-cyclodextrin/ flavor molecular inclusion complexes. J. Agri. Food Chem., 53, 338-392 (2005).

32) K. Shimada, K. Kawano, J. Ishii, T. Nakamura; Structure of inclusion complexes of cyclodextrins with triglyceride at vegetable oil/water interface. J. Food Sci., 57, 655-656 (1992).

33) C. C. Rusa, T. A. Bullions, J. Fox, F. E. Porbeni, X. Wang, A. E. Tonelli; Inclusion complex formation with a new columnar cyclodextrin Host. Langmuir, 18, 10016-10023 (2002).

34) T. B. Ho, B. R. Bhandari; Novel solid encapsulation of ethylene gas using amorphous $\alpha$-cyclodextrin and the release characteristics. J. Agr. Food Chem., 64, 3318-3323 (2016).

35) C. Turchiuli, M. T. J. Munguia, M. H. Sanchez, H. C. Ferre, E. Dumoulin; Use of different supports for oil encapsulation in powder by spray drying. Powder Tech., 225, 103-108 (2014). 


\title{
和文要約
}

\section{噴霧乾燥法による中鎖脂肪酸オイル中のアリルスルフィドの シクロデキストリンを用いた包括粉末化}

\author{
ムエンティバアンアン ${ }^{1,2,3}$ ，吉井英文 ${ }^{1,2}$ \\ 1 香川大学農学部, ${ }^{2}$ 愛媛大学連合農学研究科, ${ }^{3}$ フ工農林大学農業工学食品技術部
}

揮発性硫黄化合物は，食品の香を考える上で非常に 重要である。にんにく中のアリルスルフィドを代表と する揮発性の硫黄化合物は, 食品のおいしさに関連し て多くの研究者によって検討されており，多くの官能 検査を伴った数多くの報告がなされている. アリルス ルフィドは，非常に不安定なフレーバーであり，その 加工食品への応用は難しいのが現状である。そこで, アリルスルフィドの粉末化について，環状多糖シクロ デキストリン (CD) を用いる方法について検討した. 具体的には，中鎖脂肪酸オイル（MCTオイル）中に溶 解させた数千 ppmのアリルスルフィドと $\alpha-, \beta-$ 拉よ び $\gamma-\mathrm{CD}$ 溶液を室温で 8 時間混合覮拌後，噴霧乾燥す ることにより，アリルスルフィド包接 $\mathrm{CD}$ 粉末を作製 した．このときの噴霧条件がアリルスルフィド包接 $\mathrm{CD}$
粉末の特質に及ぼす影響について検討した。

噴霧乾燥入口空気温度 $200^{\circ} \mathrm{C}$ で作製した $\alpha-\mathrm{CD}, \beta$ $-\mathrm{CD}$ および $\gamma-\mathrm{CD}$ 粉末には, $0.78,0.17$ および $0.63,0.78$ $\mathrm{mg} / \mathrm{g}-$ powder のアリルスルフィドを含有する粉末が得 られた。粉末中のアリルスルフィド含量は，供給溶液 中のアリルスルフィド濃度にほほ比例して増加した. また，粉末中の MCT 油量の増加によるアリルスルフィ ド含有量が増加した。これは，MCTオイル中のアリル スルフィドが選択的に包接されていることを示唆して いる。噴霧乾燥入口空気温度は CD 粉末中のアリルス ルフィド量に影響を与えなかった。 $\mathrm{CD}$ 粉末中のアリ ルスルフィド量は， $\mathrm{CD}$ の空孔径と $\mathrm{CD}$ の溶解度から考 えられる被膜効果に依存すると考えられた。 